DOI $10.22363 / 2312-8143-2018-19-4-537-551$

UDC $552.08+552.12$

\title{
Mineral composition, textures and gold habit of the Hamama mineralizations (Central Eastern Desert of Egypt)
}

\author{
Abdelhalim S. Mahmoud ${ }^{1,2}$, Viktor V. Dyakonov ${ }^{1}$, \\ Maher I. Dawoud ${ }^{3}$, Alexander E. Kotelnikov ${ }^{4}$ \\ ${ }^{1}$ Sergo Ordzhonikidze Russian State Geological Prospecting University (MGRI-RSGPU) \\ 23 Miklukho-Maklaya St., Moscow, 117997, Russian Federation \\ ${ }^{2}$ Fayoum University \\ Fayoum City, 63514, Egypt \\ ${ }^{3}$ Minufiya University \\ Gamal Abdel Nasser St., Shebin El Koum, 32511, Egypt \\ ${ }^{4}$ Peoples' Friendship University of Russia (RUDN University) \\ 6 Miklukho-Maklaya St., Moscow, 117198, Russian Federation
}

\begin{abstract}
Mineralization in the Hamama area exists mainly as quartz-carbonate veins, extending along the contact between the footwall volcanics (basalt, dacite, and rhyolite) and the hanging wall volcaniclastics (laminated, massive and lapilli tuffs with minor breccia). Also, mineralization was recorded as low mineralized cavity filling dolomitic veins occupying NW-SE faults in the basalt. The principal mineralization is represented by a mineral association - quartz + dolomite + calcite + pyrite + chalcopyrite + sphalerite with varying amounts of barite, cinnabar, and galena. It is suggested that these carbonates are post-tectonic low-temperature hydrothermal solution (exhalations) filling fault zones. The injected mineralized carbonate solution dissolved the silicate minerals along contacts. This fault system was caused by the group of porphyritic rhyolite dykes extending NE-SW. The carbonates then were subjected to digenetic processes after their formation resulted in the formation of some secondary sedimentary textures (for example spherulitic, colloform and cockade textures) and dolomitization. The mineralized carbonates are rich in $\mathrm{Zn}, \mathrm{Cu}$, and occasionally $\mathrm{Pb}$ and $\mathrm{Sb}$. The cavity filling dolomitic veins within basalt show low concentration of ore minerals. The pyrite was crystallized in four phases; the first phase is well-developed pyrite that was formed from the primary hydrothermal solution. The role of bacterial action is obvious in the formation of a second phase framboidal pyrite. The third phase represented by atoll structures formed by diagenetic reworking of the framboidal pyrite. The last phase of pyrite crystallization appears as fine skeletal grains mostly attached to sericite alteration of altered volcanics. The gold and silver are concentrated mainly in the upper iron cap. Secondary supergene enrichment of gold in the oxidation zone, especially in Hamama western zone, is indicated by the reprecipitation of gold as thin filaments or rounded nano-grains along cracks of the oxidized pyrite or at the periphery of the pyrite relicts.
\end{abstract}

Keywords: Hamama, quartz-carbonate veins, hydrothermal, framboids, supergene enrichment

\section{Introduction}

The basement complex of the Central Eastern Desert of Egypt shows strong NW-SE structural trend expressed in steeply dipping ductile-brittle shear zones and dissected by 
ENE deep-seated faults [1-3]. These shear zones are host to numerous types mineralizations. Hamama is an obvious example for these fault-related mineralizations. A particular exploration challenge of the Hamama district is that it is largely affected by folding, thrusting and a later post-tectonic brittle evolution.

Although the Hamama area is considered one of the prospective areas of gold mineralizations in Egypt, however, it is little studied. The first systematic geological studies were carried out in 1977 by a team of the Egyptian Geological Survey with experts from the USSR [4]. They classified the gold-bearing ore bodies into quartz and carbonate veins and zones of hydrothermally altered rocks. Stern and Gwinn [5] through isotopic analyses explained the origin of the intrusive carbonates of the Central Eastern Desert and Sudan as a mix of recombined sedimentary carbonates and mantle fluids. Abd ElRahman [6] argue that Hamama $\mathrm{Zn}-\mathrm{Cu}-\mathrm{Ag}-\mathrm{Au}$ volcanic massive sulphides (VMS) that was formed through a limited rifting of an intra-oceanic island arc, the lowtemperature nature of the hydrothermal system and these deposits were affected by supergene processes, which led to the widespread occurrence of secondary copper minerals and gold enrichment relative to the leached base metals, especially $\mathrm{Zn}$.

The exploration team from the Geological Survey Authority [4] recommended in his report to perform additional study for the deep ore interval. Consequently, in the late 1980s, Minex Minerals Egypt drilled about 40 holes but drilling cores were not reserved. Then in 2011, Alexander Nubia commenced primary exploration drilling on the prospect, showed the existence of strong magnetic anomalies below the gossan zones. In 2015, the company name was changed to Aton Resources Inc. and still working in the site. We summarized the results of mining works in the area from the published releases in the following points:

- Hamama mineralized horizon is divided into three main zones - Hamama West, Hamama Central and Hamama East;

- the Western VMS zone is main VMS horizon traced on surface over 3,000 m but extensions along the same stratigraphic horizon extend this to about $4.5 \mathrm{~km}$;

- the Western VMS zone is steeply dipping and overturned;

- Hamama West encountered as excellent gold-silver mineralization of both the near surface Gold-Oxide Cap (the highest grade gold results found on the concession) and the deeper sulphide mineralization to host a significant resource;

- drilling at Hamama intersected high-grade semi-massive and massive volcanogenic sulphide mineralization (deep trench 68 meters in the Western VMS zone gave grading $3.07 \mathrm{~g} / \mathrm{t}$ gold and $38.1 \mathrm{~g} / \mathrm{t}$ silver), this contains a broad zone of VMS gossan with highgrade gold and silver (an oxidized "gold cap") above a primary zinc-gold-silver-rich exhalite horizon, and an extensive mineralized footwall stringer and breccia zone;

- the Gold Cap extends 650 meters along strike and averages 43.8 meters wide grading $2.05 \mathrm{~g} / \mathrm{t}$ gold and $44.7 \mathrm{~g} / \mathrm{t}$ silver;

- VMS presents as a carbonate gossan, up to $20 \mathrm{~m}$ thick over the northeastern portion and to the southwest it is seen at surface as an iron-rich gossan, up to a few meters thick;

- size and width of exhalite zone indicative of a large VMS system. 


\section{Geological setting}

Hamama area is located in the central part of the Eastern Desert of Egypt, its area is determined by the coordinates $26^{\circ} 19^{\prime}-26^{\circ} 23^{\prime} \mathrm{N}$ and $33^{\circ} 17^{\prime}-33^{\circ} 23^{\prime} \mathrm{E}$ (figure 1 ). The stratigraphic section of the ore interval and its bounding units comprises from youngest to oldest (figure 1): (1) quartz-carbonate veins (youngest), (2) post-tectonic dykes, (3) post-tectonic monzogranite, (4) post-tectonic gabbro, (5) syntectonic granitoids, (6) felsic volcanics, (7) volcaniclastic rocks, (8) porphyritic ferruginous basalt, (9) basalt with pillow lava (oldest). Mineralization in the Hamama area belongs to the quartzcarbonate-vein type deposit in greenstone rocks (figure 2, $a, b$ ). This type is commonly found in deformed greenstone belts of all ages, especially with tholeiitic basalts [7]. Each rock type will be discussed briefly in the following.

Volcanogenic facies. Volcanics and their related tuffs represent the main rock units which occupy the largest area, not only in this region but also in the Central Eastern Desert. This facies is called the greenstone belt and extends NW-SE. It consists of five types of rocks: 1 - basalt with pillow lava; 2 - porphyritic ferruginous basalt; 3 - acidic and intermediate volcanics, predominantly rhyolite, with few dacite and andesite; 4 acidic and medium lamellar, lapilli and massive tuffs, intercalated with banded iron formation (BIF); 5 - volcanic breccia.

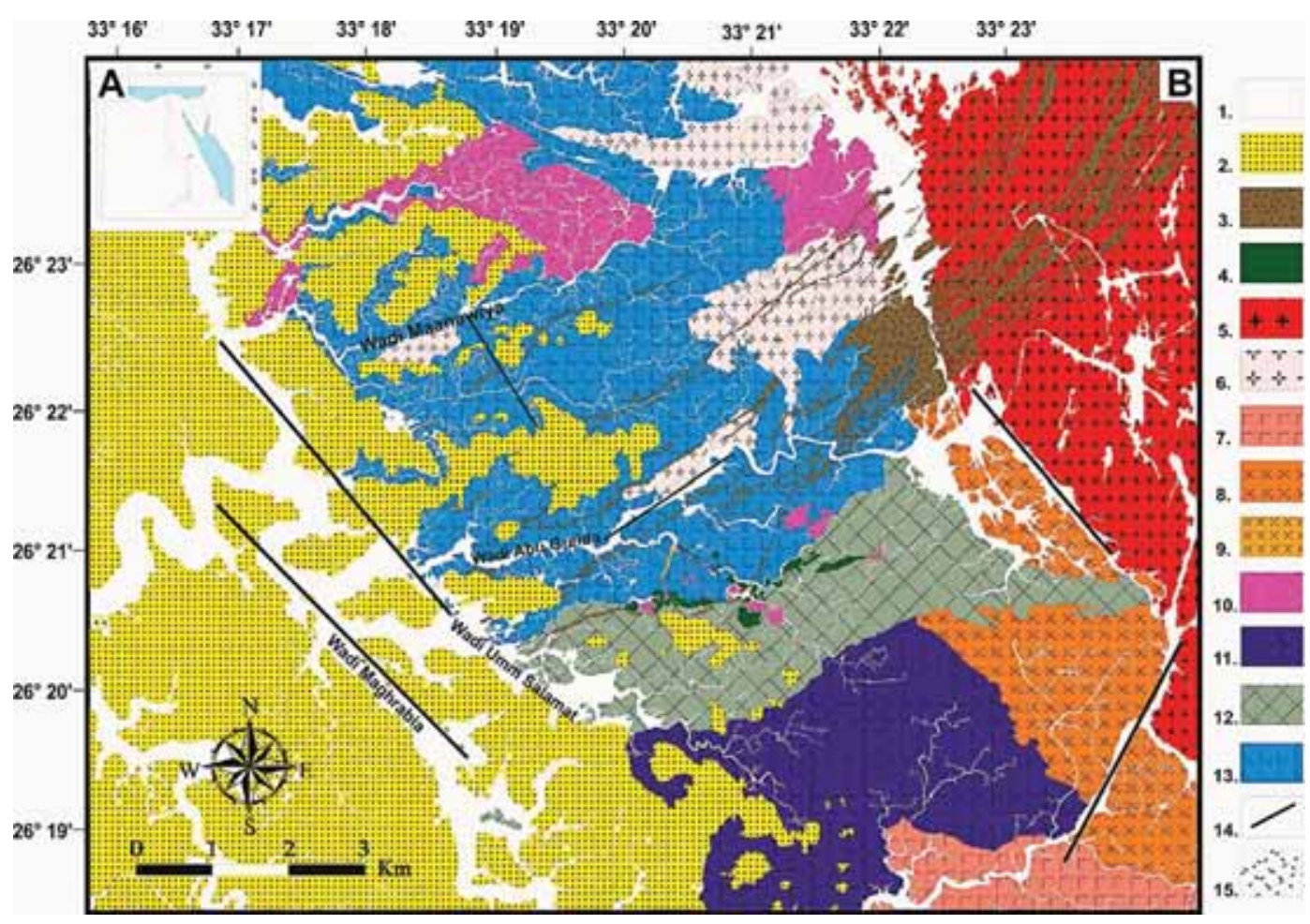

Figure 1. $A$ - location map, $B$ - geological map of the Hamama area, CED, Egypt:

1 - wadi deposits; 2 - sandstone; 3 - rhyolite dykes; 4 - quartz-carbonate ore; 5 - monzogranite; 6 - tonalite - trondhjmite; 7 - gabbro; 8 - granodirite; 9 - quartz diorite;

10 - acidic and intermediate volcanic; 11 - porphyritic ferruginous basalt; 12 - tuffs with banded iron formation;

13 - basalt with pillow lava; 14 - fault; 15 - alteration Zone 
Granitoids. It is divided into two types: 1 - syntectonic granitoids (older granites), it consist of three different types of granitic rocks: granodiorite pluton, tonalite-trondjemite pluton and small dyke-like quartz diorite pluton; 2 - post-tectonic monzogranite pluton with an ellipsoidal shape, its axis shows a NW-SE direction.

Gabbro. Large post-tectonic (younger gabbro) gabbro pluton occupies the southeastern part of the region and extends further.

Post-tectonic dykes. Two groups of dykes were recognized in the Hamama area; the majority belongs to the first group (felsic dykes), which corresponds to the composition of rhyolite and dacite, and the second group (mafic dykes) includes basalt, basaltic andesite and andesite. The first type forms a swarm of rhyolite dykes with an orthophilic structure. It originates from the monzogranite pluton and extends up to $15 \mathrm{~km}$ in the south-west direction in a radiation pattern, cutting all the above-mentioned rocks, including granitoids and a green stone belt. It is suggested that, this swarm of dykes was introduced in the post-collision, destructive boundary of slabs during stretching periods.

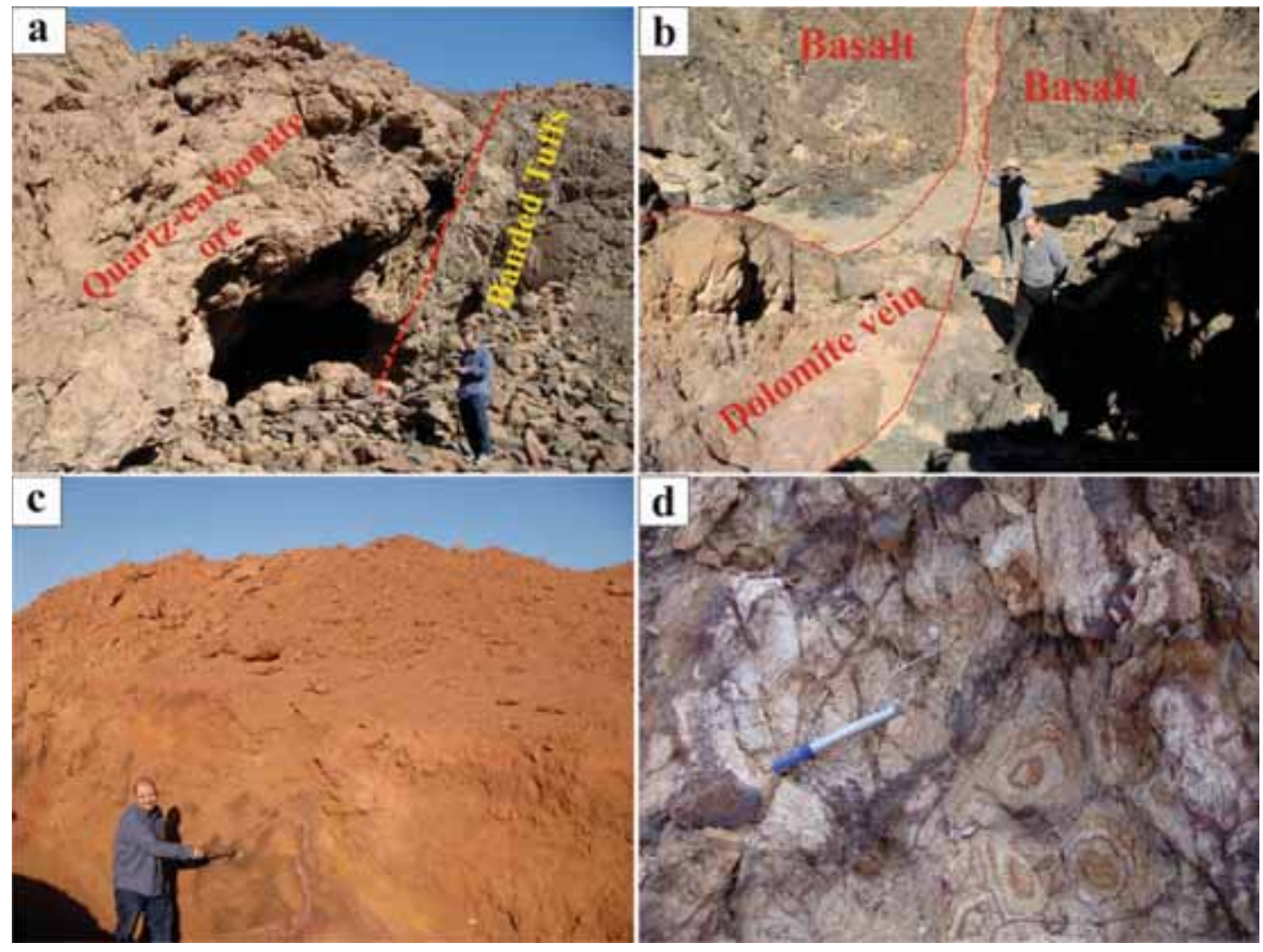

Figure 2. Different types of mineraliation in Hamama area:

$a$ - quartz carbonate body at the conact with tuffs; $b$ - cavity filling dolomitic veins in basalt; $c$ - upper oxidation zone (gossan); $d-$ foot wall alteration zones in felsic volcanics

Fault-related mineralizations. Occur basically as mineralized quartz-carbonate body fills fault zone between the basalt and tuffs (figure 2, $a$ ), within basalts (figure 2, $b$ ), and appear as thick iron cap (gossan) on the upper section (figure 2,c).

Nubian sandstone. Completely cover the western part of the area with small bodies, cover the green stone belt. It has a major unconformity with underlying volcanics. 


\section{Ore mineralogy and fabrics}

Ore petrographic and EDX analyses observations recorded in this paper were made on representative surface samples and diamond drill cores samples collected in the Hamama area. The ore interval was classified vertically into three parts as following.

\section{Fresh ore under the oxidation zone}

Sphalerite and pyrite represent the main metallic ore minerals in drill cores (figure 3 ). Mineralogically, the Hamama sulphide ores can be classified under two distinct sulphide assemblages: (1) pyrite-rich ores (pyrite + chalcopyrite + pyrohotite + covellite + arsenopyrite + galena) (figure $3, a-f$ ) and (2) sphalerite-rich ores (sphalerite + galena + chalcopyrite + pyrite) (figure $3, g-i)$. The finally mentioned is recorded mainly in the samples from deep drill holes $(>50 \mathrm{~m})$. The sulphides in the two assemblages show intimate intergrowth with quartz (figure $4, b, f, h$ ). Galena and chalcopyrite is often found in the form of inclusions or replacement of sphalerite and pyrite or deposited on their outer rims (figure $3, h$ ).
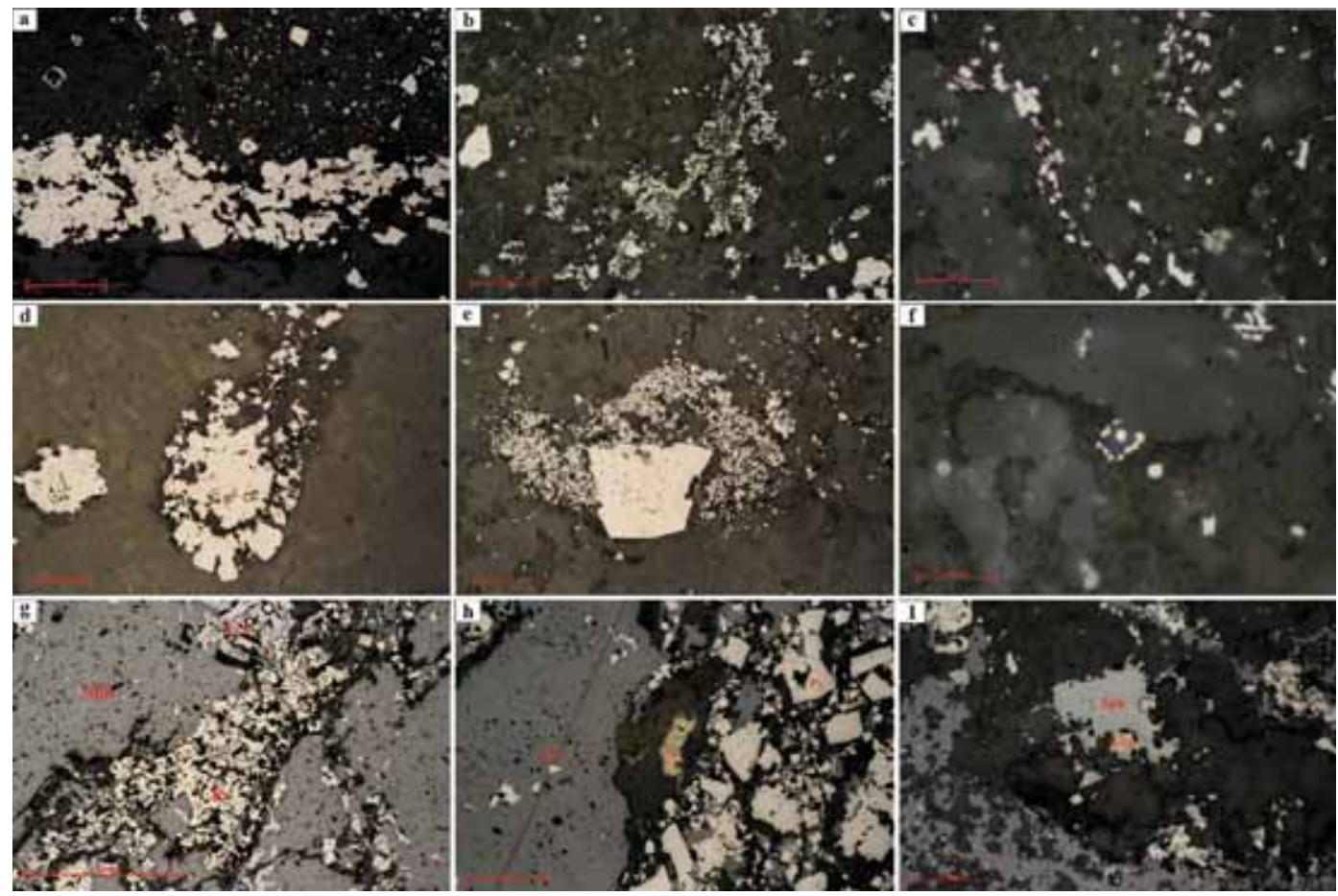

Figure 3. Photomicrographs of microfabrics in reflected light:

$a-$ primary banding shown by alternating compositional layers of pyrite and carbonates; $b-$ dendriform pyrite clusters within carbonates; $c$ - fine skeletal grains of pyrite; $d$ - atoll structure of recrystallized pyrite forming around a grain of spongy-textured pyrite; $e-$ fine skeletal grains of pyrite corroding well-crystallized pyrite; $f$ - atoll structure in fine skeletal chalcopyrite; $g$ - ineral association of sphalerite, pyrite and galena; $h$ - Rim of covellite around chalcopyrite (atoll-like) with pyrite-sphalerite (right) and sphalerite-pyrite (left) intergrowths; $i$ - sphalerite replaced by chalcopyrite to form a metasomatic reaction edge texture

The sphalerite-rich ores comprise medium to coarse, irregular patches, often hosts varying concentrations of pyrite, galena and chalcopyrite (figure $3, g, h$ ). Pyrohotite and 
rutile (figure $4, a, d$ ) are also found sporadically. Cinnabar intimately intergrown with native silver and tellurium, occur as fine inclusions in the pyrite, sphalerite and quartz (figure $4, c$ ). Chalcopyrite occasionally form replacement rims around sphalerite (figure $3, i$ ). Also, may act as filler between pyrite cubes and framboids (figure $4, h$ ).
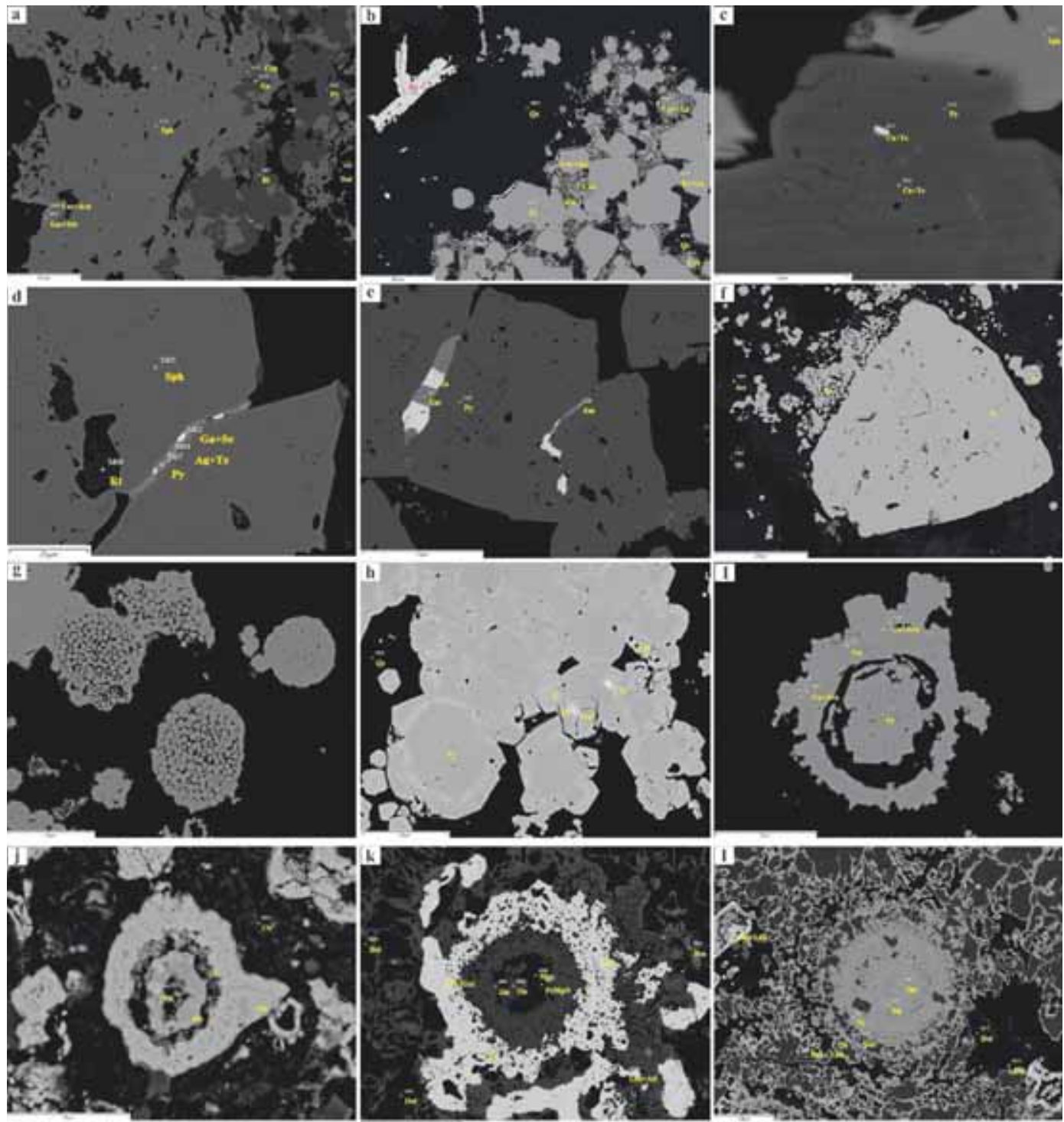

Figure 4. Backscattered electron micrographs of mineral associations and textures:

a - sphalerite porphyroblast in dolomite hosting inclusion of rutile, pyrite, chalcopyrite, and galena, and outer coating of acanthite (Ag2S), stibnite (Sb2S3) and enargite (Cu3AsS4); $b$ - silver coatings on well-crystallized pyrite and flake of barite; $c$ - fine inclusion of Te-rich cinnabar in pyrite; $d$ - precipitation of galena, pyrite and $\mathrm{Ag}$ at the boundary between sphalerite grains, note the inclusion of rutile in sphalerite; $e-$ galena and enargaite crystallized at the boundaries between pyrite grains; $f$ - fine and coarse generations of pyrite, note the fine skeletal grains are restricted to feldspar; $g$ - pyrite framboids welded with chalcopyrite; $h$ - pyrite framboids with different degrees of compactness; $i$ - framboidal Py-I, overgrown by atoll-like Py-II; $j$ - spherulite with successive layers of clay minerals and hematite; $k$ - spherulite with core of dolomite followed by zincite $(\mathrm{ZnO})$ then litharge $(\mathrm{PbO})$ and outer rim of hematite and dolomite; $I$ - spherulite with a large core of zincite and successive layers of dolomite and zincite 
Accessory amounts of rutile and covellite are disseminated within pyrite. Covellite forms as replacement rim and fillings in chalcopyrite (figure $3, h$ ). Pyrite-dominated ores exhibit well developed bands with carbonate in places (figure 3,a), comprising medium to coarse idiomorphic pyrite aggregates interlayered with minor sphalerite, magnetite and galena.

Non-metallic minerals consist mainly of quartz, dolomite (the main carbonate mineral) and calcite with little amounts of K-feldspar, clay minerals and barite (figure 5). In most of the core samples carbonates exist in the form of veins of calcite and dolomite that cut the silicate groundmass (figure $5, h, i$ ) and the older carbonate matrix. In many thin polished sections, were observed dissolution of silicates (quartz and tuffs) by later carbonates solution (figure 5, $f$ ). Also, hydrothermal solution forms a reaction rim with carbonates and silicates in cavities (figure $5, e$ ).

Four pyrite generations are texturally associated with the quartz-carbonate mixture, arranged from oldest to youngest as following.

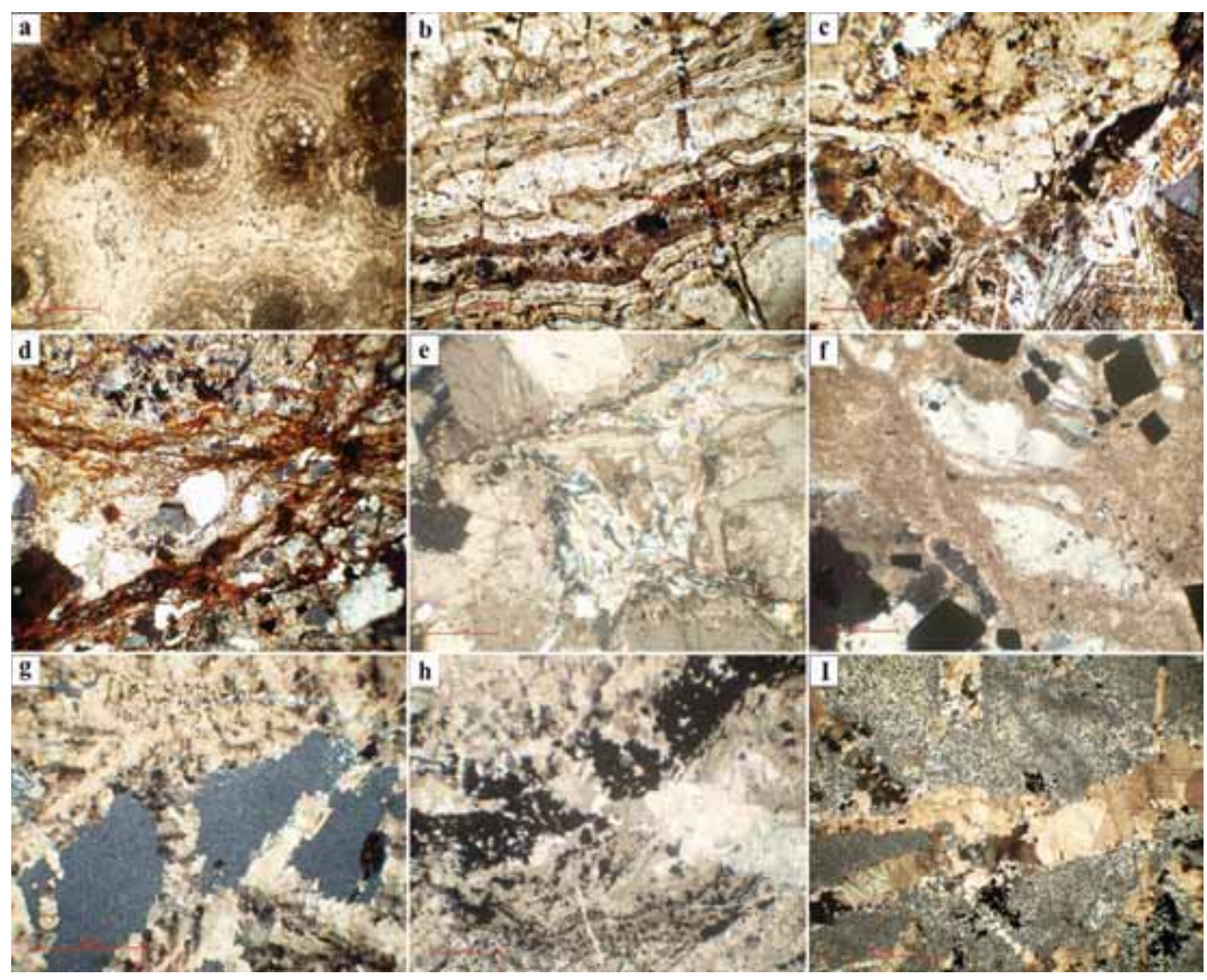

Figure 5. Photomicrographs in transmitted light:

$a$ - dolomitic spherulites with oxidized sulphide lamella and quartz in cores; $b$ - colloform texture formed by bands of carbonates, clay minerals and iron oxides; $c$ - dolomite rhombs with colloform bands; $d-$ veins of hydrothermal solution going between quartz and carbonates; $e$ - reaction rim of hydrothermal solution with calcite in basalt; $f$ - dissolution of quartz by carbonate solution; $g$ - carbonate filling interspaces between amorphous silica; $h$ - secondary calcite vein cutting a pyrite vein and the dolomitic ground mass; $i$ - a set of calcite veins cutting a mat of fine quartz grains 


\section{Coarse well-developed pyrite (Py-I)}

This phase was formed early from a low temperature hydrothermal solution so they are mostly cracked along cleavage planes. They are found as pyrite porphyroblasts, up to $500 \mathrm{~mm}$, commonly retain their idiomorphic shape (figure $3, e ; 5, f$ ). Occasionally, they host fine to medium blebs of the matrix sulphides, mostly galena and sphalerite.

\section{Framboidal pyrite (Py-II)}

It is a distinctive phase (figure $4, g, h$ ), with individual framboids range in diameter 5-50 Micron (mostly >20 Micron) while composite framboid exceeds 200 Micron. The individual framboid is composed of micro-sized pyrite cubes. The framboidal pyrites show different nucleation density where the weak dense framboid is filled by later diagenetic pyrite and chalcopyrite cementation between crystallites (figure $4, h$ ). Framboidal pyrite is abundant in many polished sections especially in pyrite-rich assemblage. It contains fine impurities of galena, acanthite, stibnite, chalcopyrite, Te and native silver. Commonly, framboidal pyrite indicates bacterial origin in reducing environments passing through various iron-sulfur compounds [8-16]. Donald and Southam [17] report FeS precipitating upon bacterial cell walls, and Pósfai et al. [18] show it forming within cells of normal sized bacteria. It is proposed that pyrite framboids precipitate rapidly in aqueous solutions, when the precursors to pyrite formation, iron monosulphides, become supersaturated, i.e. sulphide production less than iron supply $[15 ; 19]$. Generally, framboidal pyrites have low gold contents but the bacterial action mechanism may play a role in deposition of gold nanoparticles [20].

\section{Atoll structures of pyrite (Py-III)}

Pyrite atoll structures are thin rings of pyrite or chalcopyrite around a coarse nucleus of gangue minerals mainly carbonates and quartz (figure $3, d, f ; 4, i$ ). Atoll pyrite is largely associated with carbonates than quartz which indicate that their formation was associated with the injection of the carbonate solution. England and Ostwald [21] proposed that the atoll structures are derived from framboidal pyrite, through diagenetic transformation of framboidal. Atolls host fine impurities of galena and acanthite (figure 4, $i$ ).

\section{Fine skeletal pyrite (Py-IV)}

This latest generation of pyrite (figure $3, c, e ; 4, f$ ) is restricted mainly to sericite alteration product of feldspars which indicate that they were formed during the alteration stage. The solution forming the fine skeletal pyrites corroded the euhedral primary pyrites forming corrosion vacancies in its rim (figure $3, f$ ). Some of these fine idiomorphic pyrite grains exhibit zoned growth.

\section{Weakly oxidized ore}

The ore body on the surface was exposed to weathering with different degrees resulting in the destruction of the original textures and minerals of the primary ore. Because pyrite is more resistant to weathering, it left some relicts with oxidized rim of hematite (figure $6, a$ ). 

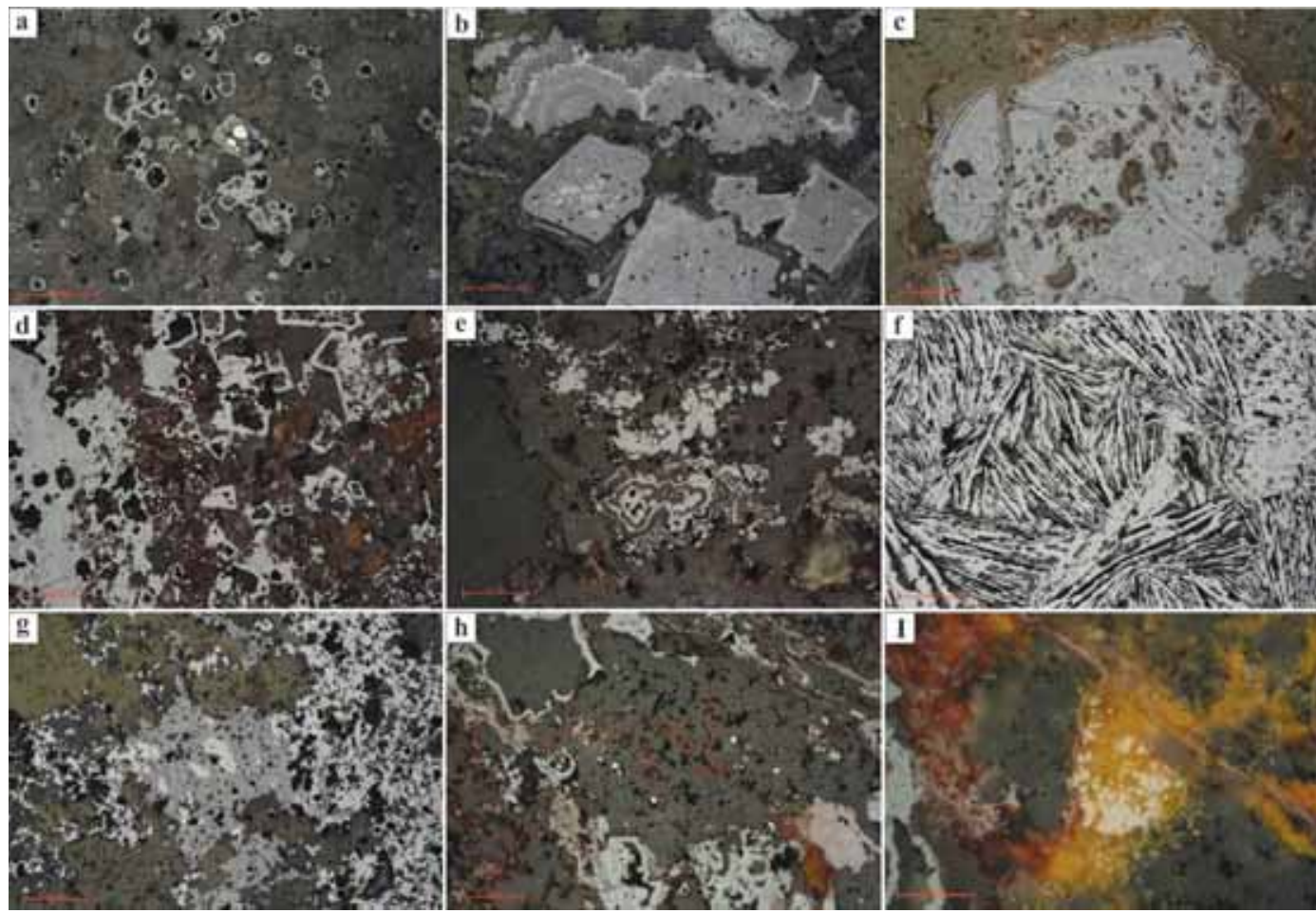

Figure 6. Photomicrographs in reflected light:

$a$ - oxidized sulphides with relict of pyrite with a rim of hematite reserving pyrite cubic shape; $b$ - colloform texture formed by bands of goethite and hematite and euhedral cubes of oxidized pyrite; $c$ - zoned iron oxides and hydroxides due to long term infiltration of fluid along the fracture of pyrites; $d$ - intensively oxidized ore forming with outer rims of oxidized pyrite in a mixture of iron oxides, clay minerals and carbonates; $e$ - oxidized framboidal pyrite and some of them surrounded by colloform hematite; $f$ - specular hematite; $g$ - intergrowth of hematite and goethite in quartz carbonate matrix; $h$ - fine pyrite relicts in oxidized sulphides; $i$ - pyrite mixed with hematite, limonite and goethite

The carbonates with their ore minerals were subjected to digenetic processes after their formation resulted in the formation of some secondary sedimentary textures. The most prominent digenetic textures include spherulitic (figure $4, l ; 5, a$ ), colloform (figure $5, b ; 6, b$ ) and cockade textures (figure $4, g, k$ ). Also, almost calcite was converted into dolomite by dolomitization. Coarse (up to $20 \mathrm{~mm}$ ) zoned dolomite rhombs were observed (figure $5, c$ ) in the core of dolomitic veins in basalt (figure 2,b).

Pyrite was oxidized into iron oxides and hydroxides as hematite, goethite and limonite with preserving its original cubic shape (figure 6, $a, b, c, d$ ). Sphalerite converted into zinc oxides, hydroxides and metal salts that are hard to identify microscopically. A prominent feature of this type is the presence of excellent colloidal masses of rhythmically layered to concentric structure. Some are composed of carbonates (dolomite) and oxidized pyrite (hematite) and outer rim of litharge (figure $4, k$ ) while other spheroids consist of alternative shells of oxidized sphalerite (zincite) with dolomite and a center consisting of gangue material (figure 4, l). It is proposed that these structures were formed by relatively rapid crystallization of a low temperature sulfide gel (colloidal dispersion). Another distinctive feature was observed where the oxidized euhedral pyrite cubes were opened after oxidation and filled with single and composite spheroidal bacterial units. Barite is a common accessory phase especially in the partially oxidized ore. Often it contains 
inclusions of acanthite. The abundance of barite fragments within these samples makes the identification of precious metal grains extremely difficult due to their similar electronic reflectivity. There are strong relation between the abundance of silver and barite.

\section{Intensively oxidized ore (gossans) and gold habit}

Although gold was detected by ICP-MS analysis with considerable amounts in massive sulphide ore, no obvious gold grains were observed in the studied sections from drill holes. The main reason is that gold is distributed and combined in the lattice of the pyrite and other sulphide minerals as micron size inclusions. As shown in the geochemical map (figure $7, f$ ), there are nano-particles of gold distributed all over the scanned area of the oxidized pyrite grain. These nano-particles were trapped along fractures (figure $7, c$ ), between oxidation zones (figure $7, b$ ), and cavities (figure $7, f$ ) or precipitated along the boundary between relict cores of pyrite and the oxidation rim (figure $7, d, e$ ).

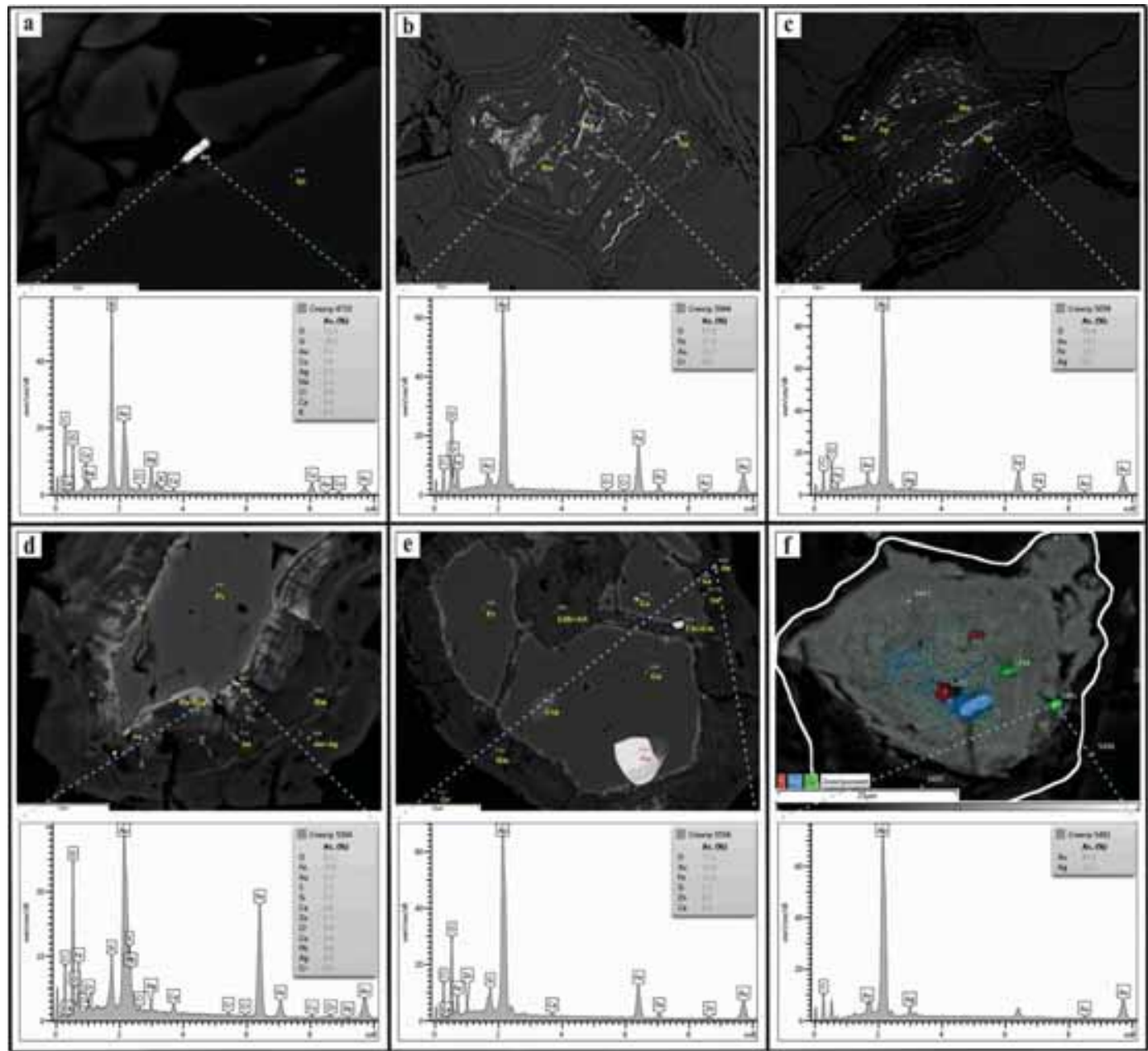

Figure 7. Backscattered electron micrographs and EDX analyses for gold in the oxidation zone: $a$ - gold flake between quartz grains; $b, c$ - thin filaments of gold in cracks and oxidation layers';

$d, e-$ fine grains of gold along the boundary between pyrite relict core and oxidation layers; $f$ - geochemical distribution of elements $\mathrm{Au}, \mathrm{Hg}$ and $\mathrm{S}$ in oxidized pyrite 
The significant feature of the iron cap is that it contains abundant gold grains and flakes. Gold is related to the oxidized pyrite or fine goethite layers forming rich clusters seem to be rich in Au and Ag. Native gold appear as thin filaments $(0.5 \mu \mathrm{m}$ width and up to $25 \mu \mathrm{m}$ length) or very fine rounded grains; their grain size ranges from 2 to $10 \mu \mathrm{m}$. They always appear in voids between layers or intergrowth between two successive layers (figure $7, b$ ). Gold grains found in samples composed of a fine goethite matrix appear related to shrinkage cracks, mixed with barite grains (figure 2). EDX analyses don't show the real composition of gold grains due to its small sizes; hence the given spectrum is disturbed by adjacent mineral composition. Common impurities in gold such as Ag, $\mathrm{Cu}$, and $\mathrm{Zn}$ appear only in trace amounts.

All primary ore minerals are altered except few fine relicts of pyrite and chalcopyrite. All metals are mobilized in primary sulphide minerals and redistributed in another forms at different depths. For example, copper minerals precipitate at the reactive redox boundary between massive sulphides ore and downward penetrate fluids producing significant supergene enrichment "blanket" zone. The enrichment zone is overlain by an intensely altered and leached Fe oxide-rich gossans (the remains of the original massive sulfide). The overall mineral assemblage of the oxidization zone can be described as a hematite-limonite-goethite-quartz assemblage bearing $\mathrm{Au}-\mathrm{Ag}$ with abundant barite as gangue mineral. Abundance of hematite compared with goethite and limonite is variable but generally hematite is much more than goethite and limonite. Clay minerals occur in between layers of botryoidal aggregates.

Botryoidal aggregates of successive layers of hematite and often clay minerals developed over cores of gangue minerals and infilling voids (figure $4, g$ ). The outer rim of these aggregates is always hematite probably due to dehydratation (aging) from goethitic phases [22].

\section{Alteration zones and quartz veins}

Footwall volcanics were affected by different types of alteration. They include sericitization, silicification, and ferrugination. The original silicate minerals completely altered to a mixture of clay mineral, talc and chlorite and stained with iron oxide solution (figure 5,d). Acidic and intermediate volcanics were more acceptable to hydrothermal alteration that appears as replacement of primary igneous glass and minerals with alteration minerals stable at the conditions of alteration, generally in low temperate range characteristic of this type $\left(150-400{ }^{\circ} \mathrm{C}\right)$. It is worth to mention that the altered felsic volcanics contain considerable amounts of monazite, zircon and rutile. The percolation of hydrothermal solutions between grains left a set of veins and channels filled with iron oxides, sericite and carbonates. The alteration minerals recorded include fine mica, clay minerals, quartz, chlorite, serpentine, carbonates, talc, kaolinite, pyrite and iron oxides. Weak alteration of some of the minerals or ground mass in the volcanic host rocks, produce an earthy aspect to the overall rock. Alteration of the glassy ground mass or fine grains is particularly susceptible producing massively silicified matrix with chlorite and sericite. At high alteration intensity, rocks may be pervasively altered, in which virtually all primary phases in the rock are altered to new hydrothermal minerals. 
Infrequently volcanics contain porous quartz barite veins with specular hematite (specularite) formed by hot solutions. The specularite is primary in origin and the veins containing it represent genetically the last phase of volcanic activity.

\section{Conclusions}

Hamama mineralization found as quartz-carbonate veins hosted in the contact of bimodal volcanic sequence and its tuffs.

The carbonates were injected as a late hydrothermal solution into the NW-SE fault zones in basalts and in their contact with volcaniclastic succession.

Carbonates with their ore lode were subjected to diagenetic processes expressed by colloform, cockade, and spherulitic textures.

Multiple generations of pyrite have been documented in both the deep sulphide ore from drill-holes and surface exposed ore. They are primary well crystallized pyrite, framboidal pyrite formed by bacterial action in reducing environment, atoll structures by reworking of framboids, and fine skeletal pyrite related to later sericite alteration of volcanic rocks.

Intensive alteration of the ore body by the supergene fluids redistributed gold and base metals in the iron cap zone significant supergene enrichment zone with $\mathrm{Zn}, \mathrm{Cu}, \mathrm{Ag}, \mathrm{Au}$, and $\mathrm{Hg}$. In the primary ore gold is incorporated to the crystal lattice of sulphide minerals which represent a big challenge for its extraction.

\section{Acknowledgements}

We would like to express our deepest sincere gratitude to Mr. Javier Orduña, Exploration Manager, "Aton Resources" and all the staff of Hamama camp for providing accommodation and drill core samples during the course of the field trip. Also grateful to the laboratories of Saint Petersburg University, especially Dr. Mohamed Ghoneim for his kind and gentle treatment and some facilities throughout the sem work. The authors also wish to express their thanks to Prof. Vladimir Alexandrovich Utenkov, Head of the Mineralogy and Petrography Laboratory, Russian State Geological Prospecting University for his valuable help.

\section{References}

[1] Bennett J., Mosley P. Tiered-tectonics and evolution, Eastern Desert and Sinai, Egypt. Colloquium on African geology, 1987, 14, 79-82.

[2] Garson M.S., Krs M. Geophysical and geological evidence of the relationship of Red Sea transverse tectonics to ancient fractures. Geological Society of America Bulletin, 1976, 87(2), 169-181.

[3] Greiling R., Kröner A., El-Ramly M., Rashwan A. Structural relationships between the southern and central parts of the Eastern Desert of Egypt: details of a fold and thrust belt. The Pan-African Belt of Northeast Africa and Adjacent Areas. 1988, 121-146.

[4] Abdel Nabi A., Aboul Wafa N., El Hawaary M., Sabet A. Results of prospecting for gold and rare metals in Wadis Safaga, El Barrud, El Marah and Hamama. Internal Report of the Geological Survey of Egypt, 1977, 24.

[5] Stern R.J., Gwinn C.J. Origin of late Precambrian intrusive carbonates, Eastern Desert of Egypt and Sudan: C, O and Sr isotopic evidence. Precambrian Research, 1990, 46(3), 259-272.

[6] Abd El-Rahman Y., Surour A.A., El-Manawi A.H.W., El-Dougdoug A.-M.A., Omar S. Regional setting and characteristics of the Neoproterozoic Wadi Hamama $\mathrm{Zn}-\mathrm{Cu}-\mathrm{Ag}-\mathrm{Au}$ prospect: evidence for an intra-oceanic island arc-hosted volcanogenic hydrothermal system. International Journal of Earth Sciences, 2015, 104(3), 625-644. 
[7] Dubé B., Gosselin P. Greenstone-hosted quartz-carbonate vein deposits. Mineral Deposits of Canada: a synthesis of major deposit-types, district metallogeny, the evolution of geological provinces, and exploration methods. Geological Association of Canada, Mineral Deposits Division, Special Publication, 2007, 5, 49-73.

[8] Folk R.L. Nannobacteria and the formation of framboidal pyrite: textural evidence. Journal of Earth System Science, 2005, 114(3), 369-374.

[9] Garcia-Guinea J., Martinez-Frias J., Gonzalez-Martin R., Zamora L. Framboidal pyrites in antique books. Nature, 1997, 388(6643), 631.

[10] Love L. Early diagenetic iron sulphide in recent sediments of the Wash (England). Sedimentology, 1967, 9(4), 327-352.

[11] Love L.G. Mircro-organisms and the presence of syngenetic pyrite. Quarterly Journal of the Geological Society, 1957, 113(1-4), 429-440.

[12] Love L.G. Biogenic primary sulfide of the Permian Kupferschiefer and Marl Slate. Economic Geology, 1962, 57(3), 350-366.

[13] Love L.G., Al-Kaisy A.T., Brockley H. Mineral and organic material in matrices and coatings of framboidal pyrite from Pennsylvanian sediments, England. Journal of Sedimentary Research, 1984, 54(3).

[14] Love L.G., Murray J. Biogenic pyrite in recent sediments of Christchurch Harbour, England. American Journal of Science, 1963, 261(5), 433-448.

[15] Raiswell R. Pyrite texture, isotopic composition and the availability of iron. American Journal of Science, 1982, 282(8), 1244-1263.

[16] Suits N.S., Wilkin R.T. Pyrite formation in the water column and sediments of a meromictic lake. Geology, 1998, 26(12), 1099-1102.

[17] Donald R., Southam G. Low temperature anaerobic bacterial diagenesis of ferrous monosulfide to pyrite. Geochimica et Cosmochimica Acta, 1999, 63(13), 2019-2023.

[18] Pósfai M., Buseck P.R., Bazylinski D.A., Frankel R.B. Reaction sequence of iron sulfide minerals in bacteria and their use as biomarkers. Science, 1998, 280(5365), 880-883.

[19] Passier H.F., Middelburg J.J., de Lange G.J., Böttcher M.E. Pyrite contents, microtextures, and sulfur isotopes in relation to formation of the youngest eastern Mediterranean sapropel. Geology, 1997, 25(6), 519-522.

[20] Konishi Y., Tsukiyama T., Tachimim T., Saitoh N., Nomura T., Nagamine S. Microbial deposition of gold nanoparticles by the metal-reducing bacterium Shewanella algae. Electrochimica Acta, 2007, 53(1), 186-192.

[21] England B., Ostwald J. Framboid-derived structures in some Tasman fold belt base-metal sulphide deposits, New South Wales, Australia. Ore Geology Reviews, 1993, 7(5), 381-412.

[22] Capitán A., Nieto J.M., Sáez R., Almodóvar R. Caracterización textural y mineralógica del gossan de Filón Sur (Tharsis, Huelva). Boletín de la Sociedad Española de Mineralogía, 2003, (26), $45-58$.

(C) Mahmoud A.S., Dyakonov V.V., Dawoud M.I., Kotelnikov A.E., 2018 This work is licensed under a Creative Commons Attribution 4.0 International License

\section{Article history:}

Received: September 05, 2018

Revised: October 27, 2018

Accepted: November 02, 2018

\section{For citation:}

Mahmoud A.S., Dyakonov V.V., Dawoud M.I., Kotelnikov A.E. (2018). Mineral composition, textures and gold habit of the Hamama mineralizations (Central Eastern Desert of Egypt). RUDN Journal of Engineering Researches, 19(4), 537-551. DOI 10.22363/2312-8143-2018-19-4-537551 


\title{
Bio Notes:
}

Abdelhalim S. Mahmoud - PhD student, Sergo Ordzhonikidze Russian State Geological Prospecting University (MGRI-RSGPU). Teaching assistant, Geology Department, Faculty of Science, Fayoum University. Research interests: mineralogy, petrology, geochemistry, and ore deposits. Contact information: e-mail: halim.geologist@mail.ru

Viktor V. Dyakonov - Doctor of Science in Geology, Professor, Head of Department of the general geology and geomapping, Sergo Ordzhonikidze Russian State Geological Prospecting University. Research interests: geology, mineral deposits, mineral exploration. Contact information: e-mail: mdf.rudn@mail.ru

Maher I. Dawoud - Professor, Professor of Mineralogy, Petrology, Geochemistry and Ore Deposits, Geology Department, Faculty of Science, Minufiya University. Research interests: mineralogy, petrology, and ore deposits. Contact information: e-mail: Dawoud_99@yahoo.com

Alexander E. Kotelnikov - PhD in Geology, Assistant Professor, Department of Mineral Developing and Oil \& Gas Engineering, Engineering Academy, Peoples' Friendship University of Russia (RUDN University). Research interests: geology, mineral deposits, mineral exploration, search of deposits. Contact information: e-mail: kotelnikov-ae@rudn.ru

Научная статья

\section{Минеральный состав, текстура и формы золотой минерализации Хамама (центральная часть Восточной пустыни Египта)}

\author{
А.Ш. Махмуд ${ }^{1,2}$, В.В. Дьяконов ${ }^{1}$, М.И. Давуд ${ }^{3}$, А.Е. Котельников ${ }^{4}$ \\ ${ }^{1}$ Российский государственный геологоразведочный университет им. С. Орджоникидзе \\ Российская Федерация, 117997, Москва, ул. Миклухо-Маклая, 23 \\ ${ }^{2}$ Университет Фаюма \\ Египет, 63514, Аль-Фаюм \\ ${ }^{3}$ Университет Менуфии \\ Eгипет, 32511, Аль-Минуфье \\ ${ }^{4}$ Российский университет дружбы народов \\ Российская Федерация, 117198, Москва, ул. Миклухо-Маклая, 6
}

\begin{abstract}
Минерализация в районе Хамама (Натата) представлена преимущественно в виде кварцкарбонатных жил, простирающихся вдоль контакта между лежачим боком вулканогенных пород (базальты, дациты и риолиты) и висячим блоком вулканогенно-осадочных пород (слоистые, массивные и лапиллиевые туфы с небольшим количеством брекчий). Также минерализация отмечена в виде слабо минерализованных доломитовых жил, заполняющих трещины северо-западного - южно-восточного простирания в базальтах. Основную минерализацию можно описать через минеральную ассоциацию - кварц + доломит + кальцит + пирит + халькопирит + сфалерит с различным количеством барита, киновари и галенита. Предположительно, эти карбонатные породы образовались из посттектонических низкотемпературных
\end{abstract}


гидротермальных растворов (эманации газа из магмы), заполняющих зоны разломов. Привносимые минерализованные карбонатные растворы преобразовали кремнистые породы вдоль контакта. Система разломов сформировалась за счет внедрения риолит-порфировых даек северо-восточного простирания. Карбонатные породы подверглись дигенетическим процессам, что привело к появлению некоторых вторичных осадочных текстур (например, сферолитовой, колломорфной и кокардовой) и доломитизации. Минерализованные карбонатные породы обогащены цинком, медью и реже свинцом и сурьмой. Доломитовые жилы, заполняющие трещины, обладают низким содержанием рудных минералов. Кристаллизация пирита - четырехфазная. Первая фаза - хорошо раскристаллизованный пирит, появившийся из первичного гидротермального раствора. Жизнедеятельность бактерий обусловила формирование второй фазы - фрамбоидного пирита. Третья фаза (с кольцеобразной структурой) образовалась за счет диагенетической перестройки фрамбоидного пирита. Последняя фаза кристаллизации пирита проявляется в виде тонкого скелетного зерна, главным образом прикрепленного к серицитизации измененных вулканических пород. Золото и серебро сконцентрированы в основном в верхней чести «железной шляпы». Вторичное гипергенное обогащение золота в зоне окисления, особенно в западной зоне Хамама (Hamama), представлено переотложенным золотом в виде тонких нитеобразных или округлых нанозерен, расположенных вдоль трещин окисленного пирита или по периферии реликтов пирита.

Ключевые слова: Хамама, кварц-карбонатные жилы, гидротермальный, фрамбоиды, гипергенное обогащение

\section{Список литературы}

[1] Bennett J., Mosley P. Tiered-tectonics and evolution, Eastern Desert and Sinai, Egypt // Colloquium on african geology. 1987. No. 14. Pp. 79-82.

[2] Garson M.S., Krs M. Geophysical and geological evidence of the relationship of Red Sea transverse tectonics to ancient fractures // Geological Society of America Bulletin. 1976. Vol. 87. No. 2. Pp. 169-181.

[3] Greiling R., Kröner A., El-Ramly M., Rashwan A. Structural relationships between the southern and central parts of the Eastern Desert of Egypt: details of a fold and thrust belt. The Pan-African Belt of Northeast Africa and Adjacent Areas. 1988. Pp. 121-146.

[4] Abdel Nabi A., Aboul Wafa N., El Hawaary M., Sabet A. Results of prospecting for gold and rare metals in Wadis Safaga, El Barrud, El Marah and Hamama // Internal Report of the Geological Survey of Egypt. 1977. Vol. 24.

[5] Stern R.J., Gwinn C.J. Origin of late Precambrian intrusive carbonates, Eastern Desert of Egypt and Sudan: C, O and Sr isotopic evidence // Precambrian Research. 1990. Vol. 46. No. 3. Pp. 259272.

[6] Abd El-Rahman Y., Surour A.A., El-Manawi A.H.W., El-Dougdoug A.-M.A., Omar S. Regional setting and characteristics of the Neoproterozoic Wadi Hamama $\mathrm{Zn}-\mathrm{Cu}-\mathrm{Ag}-\mathrm{Au}$ prospect: evidence for an intra-oceanic island arc-hosted volcanogenic hydrothermal system // International Journal of Earth Sciences. 2015. Vol. 104. No. 3. Pp. 625-644.

[7] Dubé B., Gosselin P. Greenstone-hosted quartz-carbonate vein deposits. Mineral Deposits of Canada: a synthesis of major deposit-types, district metallogeny, the evolution of geological provinces, and exploration methods // Geological Association of Canada, Mineral Deposits Division, Special Publication. 2007. No. 5. Pp. 49-73.

[8] Folk R.L. Nannobacteria and the formation of framboidal pyrite: Textural evidence // Journal of Earth System Science. 2005. Vol. 114. No. 3. Pp. 369-374.

[9] Garcia-Guinea J., Martinez-Frias J., Gonzalez-Martin R., Zamora L. Framboidal pyrites in antique books. Nature. 1997. Vol. 388. No. 6643. P. 631.

[10] Love L. Early diagenetic iron sulphide in recent sediments of the Wash (England) // Sedimentology. 1967. Vol. 9. No. 4. Pp. 327-352.

[11] Love L.G. Mircro-organisms and the presence of syngenetic pyrite // Quarterly Journal of the Geological Society. 1957. Vol. 113. No. 1-4. Pp. 429-440. 
[12] Love L.G. Biogenic primary sulfide of the Permian Kupferschiefer and Marl Slate // Economic Geology. 1962. Vol. 57. No. 3. Pp. 350-366.

[13] Love L.G., Al-Kaisy A.T., Brockley H. Mineral and organic material in matrices and coatings of framboidal pyrite from Pennsylvanian sediments, England // Journal of Sedimentary Research. 1984. Vol. 54. No. 3.

[14] Love L.G., Murray J. Biogenic pyrite in recent sediments of Christchurch Harbour, England // American Journal of Science. 1963. Vol. 261. No. 5. Pp. 433-448.

[15] Raiswell R. Pyrite texture, isotopic composition and the availability of iron // American Journal of Science. 1982. Vol. 282. No. 8. Pp. 1244-1263.

[16] Suits N.S., Wilkin R.T. Pyrite formation in the water column and sediments of a meromictic lake // Geology. 1998. Vol. 26. No. 12. Pp. 1099-1102.

[17] Donald R., Southam G. Low temperature anaerobic bacterial diagenesis of ferrous monosulfide to pyrite // Geochimica et Cosmochimica Acta. 1999. Vol. 63. No. 13. Pp. 2019-2023.

[18] Pósfai M., Buseck P.R., Bazylinski D.A., Frankel R.B. Reaction sequence of iron sulfide minerals in bacteria and their use as biomarkers// Science. 1998. Vol. 280. No. 5365. Pp. 880-883.

[19] Passier H.F., Middelburg J.J., de Lange G.J., Bottcher M.E. Pyrite contents, microtextures, and sulfur isotopes in relation to formation of the youngest eastern Mediterranean sapropel // Geology. 1997. Vol. 25. No. 6. Pp. 519-522.

[20] Konishi Y., Tsukiyama T., Tachimim T., Saitoh N., Nomura T., Nagamine S. Microbial deposition of gold nanoparticles by the metal-reducing bacterium Shewanella algae // Electrochimica Acta. 2007. Vol. 53. No. 1. Pp. 186-192.

[21] England B., Ostwald J. Framboid-derived structures in some Tasman fold belt base-metal sulphide deposits, New South Wales, Australia // Ore Geology Reviews. 1993. Vol. 7. No. 5. Pp. 381-412.

[22] Capitán A., Nieto J.M., Sáez R., Almodóvar R. Caracterización textural y mineralógica del gossan de Filón Sur (Tharsis, Huelva) // Boletín de la Sociedad Española de Mineralogía. 2003. No. 26. Pp. 45-58.

\section{История статьи:}

Дата поступления в редакцию: 05 сентября 2018

Дата поступления доработанного текста: 27 октября 2018

Дата принятия к печати: 02 ноября 2018

\section{Для цитирования:}

Mahmoud A.S., Dyakonov V.V., Dawoud M.I., Kotelnikov A.E. Mineral composition, textures and gold habit of the Hamama mineralizations (Central Eastern Desert of Egypt) (Минеральный состав, текстура и формы золотой минерализации Хамама (центральная часть Восточной пустыни Египта) // Вестник Российского университета дружбы народов. Серия: Инженерные исследования. 2018. Т. 19. № 4. C. 537-551. DOI 10.22363/2312-8143-2018-19-4$537-551$

\section{Сведения об авторах:}

Махмуд Абделхалим - аспирант, Российский государственный геологоразведочный университет имени Серго Орджоникидзе (МГРИ-РГГРУ). Ассистент кафедры геологии факультета естественных наук, Университет Фаюма (Египет). Область научных интересов: минералогия, петрология, геохимия, рудные месторождения. Контактная информация: e-mail: halim.geologist@mail.ru

Дьяконов Виктор Васильевич - доктор геолого-минералогических наук, профессор, заведующий кафедрой общей геологии и геокартирования, Российский государственный геологоразведочный университет имени Серго Орджоникидзе (МГРИ-РГГРУ). Область научных интересов: геология, месторождения полезных ископаемых, поиски месторождений. Контактная информация: e-mail: mdf.rudn@mail.ru 
Давуд Махер - профессор, профессор минералогии, петрологии и полезных ископаемых кафедры геологии факультета естественных наук, Университет Менуфии (Египет). Область научных интересов: минералогия, петрология, геохимия, полезные ископаемые. Контактная информация: e-mail: Dawoud_99@yahoo.com

Котельников Александр Евгеньевич - кандидат геолого-минералогических наук, доцент департамента недропользования и нефтегазового дела Инженерной академии, Российский университет дружбы народов (РУДН). Область научных интересов: геология, месторождения полезных ископаемых, поиски месторождений. Контактная информация: e-mail: kotelnikov-ae@rudn.ru 